\author{
А. Г. КРУТЬ, В. В. ГОРАЧУК
}

\title{
ПЕРСПЕКТИВИ ВИКОРИСТАННЯ СТАНДАРТІВ НА СИСТЕМИ УПРАВЛІННЯ ЯКІСТЮ В ЗАКЛАДАХ ОХОРОНИ ЗДОРОВ'Я
}

\author{
Національна медична академія післядипломної освіти імені П. Л. Шупика, м. Київ, Україна
}

\begin{abstract}
Мета: визначити відмінності вимог стандарту «ДСТУ EN 15224:2019 (EN 15224:2016, IDT). Системи управління якістю. EN ISO 9001:2015 у сфері охорони здоров'я» від стандарту «ДСТУ ISO 9001:2015 (ISO 9001:2015, IDT). Системи управління якістю. Вимоги».

Матеріали і методи. Використано наукові літературні джерела, вітчизняні й міжнародні документи, стандарти на системи управління якістю. Застосовано методи системного підходу, системного й порівняльного аналізу, контентаналізу, графрічний.

Результати. У специсрічному для сфрери охорони здоров'я стандарті більш детально представлені характеристики якості медичної допомоги (відповідність потребам пацієнта, доступність, безперервність, ефективність, результативність, неупередженість, безпека, своєчасність, наукова обґрунтованість, орієнтованість на пацієнта, залучення пацієнта) на відміну від існуючих (ефективність, результативність, справедливість, орієнтованість на пацієнта, безпека, своєчасність). Уточнено поняття потреб пацієнта в медичній допомозі як відхилення поточного стану здоров'я від бажаного. Наголошено, що процесний підхід у закладі охорони здоров'я має бути зосереджений на клінічних процесах, а ризик-орієнтоване мислення - на безпеці пацієнта та розробці превентивних заходів. Рекомендовано здійснювати управління клінічними процесами на основі циклу Демінга (PDCA). Структура процесів представлена клінічними процесами, процесами управління ресурсами, менеджменту, дослідними та навчальними процесами. Підкреслено важливість формування, накопичення та використання власної бази знань в закладах охорони здоров'я.

Висновки. Досліджуваний стандарт, специфічний для ссрери охорони здоров'я, після введення в дію в Україні, доповнить арсенал управлінських інструментів із розробки, впровадження та підтримки орункціонування систем управління якістю в закладах охорони здоров'я.
\end{abstract}

КЛЮчОВІ СЛОВА: стандарт; система управління якістю; заклади охорони здоров'я; медична допомога.

Підтримка та відновлення здоров'я громадян визначені статтею 3 Конституції України загальнодержавним пріоритетом [5]. Разом із тим, міжнародні стратегії збереження здоров'я та відповідні їм вітчизняні спрямування вже більш як 20 років націлені не лише на надання медичної допомоги населенню, але й на відповідність запитам суспільства щодо її якості $[6,13]$.

Незважаючи на певні зусилля державних, галузевих і суспільних інституцій, якість медичної допомоги залишається актуальною проблемою як для сорери охорони здоров'я, зокрема, закладів охорони здоров'я, - надавачів медичних послуг, так і для громадян України як споживачів цих послуг [11]. Вирішення проблеми знаходиться, зокрема, у площині розвитку регуляторних механізмів забезпечення якості, одним 3 яких $€$ сертифрікація системи управління якістю закладу охорони здоров'я на відповідність вимогам національного стандарту ДСТУ ISO серії 9000 [10]. Наявність сертифікованої системи управління якістю засвідчує спроможність закладу охорони здоров'я надавати медичні послуги більш високого рівня якості, ніж при дотриманні ліцензійних вимог, та постійно підвищувати якість медичного обслуговування пацієнтів.

(с) А. Г. Круть, В. В. Горачук, 2019
За даними МОЗ України, у 2018 р. 129 закладів охорони здоров'я сертифікували свої системи управління якістю (35 - державної, 48 - комунальної, 46 - приватної фрорми власності), у 2017 р. - 95 (26 - державної, 30 - комунальної, 39 - приватної фооми власності), у 2016 р. - 18 (по 6 закладів кожної фрорми власності) [3, 4]. Зважаючи на те, що в Україні більше 3,5 тис. закладів охорони здоров'я, можна зробити висновок, що зазначений механізм регулювання якості медичної допомоги недостатньо поширений в Україні.

Важливим $є$ й той фракт, що до певного часу існували державні мотиваційні механізми сертифікації, а саме, обов'язкова наявність сертифіката відповідності системи управління якістю вимогам національного стандарту ДСТУ ISO серії 9000 для отримання вищої акредитаційної категорії закладами охорони здоров'я, що надають спеціалізовану та високоспеціалізовану медичну допомогу [7]. Постановою КМУ від 13 березня 2019 р. № 215 проходження акредитації для закладів охорони здоров'я з 01.01.2019 р. стало добровільним [8]. Це відповідає міжнародним підходам до використання стандартів, сертифрікації й акредитації закладів охорони здоров'я; разом із тим, сертифрікація організацій в світі набула статусу одного із важливих механізмів забезпечення якості 
й стала нормою у відносинах між надавачами і споживачами продукції/послуг будь-якого виду. Дотримання такого підходу визнано дослідниками стратегічною передумовою входження України до європейської економічної спільноти [1, 2].

Однак у нашій країні за умов добровільного проходження акредитації, слабкого розвитку ринку і культури відносин між замовниками і надавачами медичних послуг цілком можливе зниження або й повна втрата зацікавленості керівників медичних установ у сертифрікації своїх систем управління. Водночас використання стандартів на системи управління якістю надає можливість менеджерам керувати системою не на свій розсуд, спираючись лише на власні знання та досвід і/або поради оточуючих, а шляхом застосування такого сучасного і досконалого інструменту, як стандарт управлінської діяльності.

На сьогодні є чинним міжнародний стандарт, специфічний для сорери охорони здоров'я, «EN 15224:2016 (версія en) Quality management systems - EN ISO 9001:2015 for healthcare». 301.01 .2020 р. в Україні набуває чинності його вітчизняний аналог «ДСТУ ЕN 15224:2019 (EN 15224:2016, IDT). Системи управління якістю. EN ISO 9001:2015 у сорері охорони здоров'я» [9]. Отже, керівники закладів охорони здоров'я найближчим часом отримають специфічний для сорери охорони здоров'я стандарт для побудови і підтримки фрункціонування системи управління якістю в підпорядкованому закладі. Перш ніж використовувати цей стандарт необхідно провести системний аналіз його вимог та зрозуміти відмінності від універсального стандарту «ДСТУ ISO 9001:2015 (ISO 9001:2015, IDT). Системи управління якістю. Вимоги», в чому полягала актуальність даного дослідження.

Мета дослідження: визначити відмінності вимог стандарту «ДСТУ ЕN 15224:2019 (ЕN 15224:2016, IDT). Системи управління якістю. EN ISO 9001:2015 у сорері охорони здоров'я» від стандарту «ДСТУ ISO 9001:2015 (ISO 9001:2015, IDT). Системи управління якістю. Вимоги».

Матеріали і методи. При формуванні методології даного дослідження використано методи системного підходу, системного й порівняльного аналізу, контент-аналізу, графічний. Матеріалами дослідження слугували наукові літературні джерела (4 од.), вітчизняні й міжнародні документи (8 од.), стандарти на системи управління якістю (2 од.).

Результати дослідження та їх обговорення. Результати контент-аналізу стандарту «ДСТУ EN 15224:2019 (EN 15224:2016, IDT). Системи управління якістю. EN ISO 9001:2015 у сорері охорони здоров'я» засвідчили ряд його відмінностей і специфічних особливостей порівняно 3 універсальним стандартом «ДСТУ ISO 9001:2015 (ISO 9001:2015, IDT). Системи управління якістю.
Вимоги» (відповідний міжнародний стандарт «ISO 9001:2015 Quality management systems Requirements») [14].

Так, у стандарті для сфери охорони здоров'я повністю витримані структура й зміст універсального стандарту за 10-ма розділами, але до тексту внесені доповнення та примітки зі специфічними вимогами до сорери охорони здоров'я. В додатках до стандарту ці вимоги детально роз'яснюються.

Відмінності стандарту для сорери охорони здоров'я полягають, зокрема, в уточненні термінології. Це дозволить керівникам закладів охорони здоров'я, аудиторам, органам, що здійснюють інші контрольні функції, медичним працівникам, пацієнтам однозначно інтерпретувати поняття та розмовляти на спільній зрозумілій мові стосовно якості медичної допомоги.

Наприклад, у стандарті для сорери охорони здоров'я чітко представлені такі характеристики якості медичної допомоги:

1) відповідний, правильний догляд, що означає надання медичної допомоги відповідно до визначених потреб пацієнта, які ґрунтуються на ретельних даних анамнезу, обстеження, спостережень. Не допускається перевищення обсягу обстеження і лікування стосовно визначених потреб;

2) придатність або доступність, досяжність до пацієнта саме тих послуг, які може запропонувати цей заклад охорони здоров'я;

3) безперервність медичної допомоги, що означає надання послуги шляхом забезпечення оптимізованого ланцюга медичних послуг, до якого можуть бути задіяні різні види медичної допомоги та різні заклади охорони здоров'я;

4) ефрективність - очікуваний позитивний клінічний результат; відсутність ушкоджень, пов'язаних із наданням медичної допомоги;

5) результативність - найкраще можливе співвідношення між досягнутими результатами та використаними ресурсами;

6) неупередженість - надання медичної допомоги незалежно від статі, сексуального, культурного, етнічного, соціального, мовного або іншого походження;

7) надання медичної допомоги на основі науково обґрунтованих знань;

8) орієнтованість на пацієнта на основі персоніфікованого підходу й за умови його усвідомленої згоди;

9) залучення пацієнта, тобто, взаємодія з ним при плануванні й виконанні медичних заходів;

10) безпека пацієнта - діяльність з ідентифрікації та контролю ризиків, пов'язаних із наданням медичних послуг, та усунення всіх передбачуваних небезпек;

11) своєчасність - медичні послуги повинні надаватися вчасно, з урахуванням оцінки потреб пацієнта, гостроти і тяжкості захворювання. 
Наведений перелік характеристик є надзвичайно важливим, оскільки, за даними наукових досліджень, визначення характеристик якості триває досить довго - 31860 р., і включає погляди Томаса Сиденгама, А. Донабедіана, John Ovretveit, експертів ВОО3, Інституту медицини США, ОЕСР. Ці погляди певним чином відрізняються, а закладам охорони здоров'я на їх основі пропонують самостійно визначати ці характеристики з урахуванням місцевого контексту [12]. Тому чітке наведення характеристик якості в стандарті, на відміну від існуючих найпоширеніших шести (есрективність, результативність, справедливість, орієнтованість на пацієнта, безпека, своєчасність), може значно полегшити це завдання керівникам закладів охорони здоров'я.

У стандарті для сфери охорони здоров'я також чітко визначено поняття потреб у медичній допомозі (health need). Вони представлені як відхилення поточного стану здоров'я пацієнта порівняно 3 критеріями бажаного стану здоров'я. Важливість цього поняття полягає в тому, що його розуміння тісно пов'язано з основною метою діяльності закладу охорони здоров'я у сфері якості - забезпечення задоволеності замовників на основі визначення їх потреб у медичній допомозі та очікувань від системи медичної допомоги.

Значним надбанням стандарту для сорери охорони здоров'я варто вважати інтерпретацію поняття процесного підходу та елементів системи управління якістю для медичних організацій.

Так, процесний підхід повинен бути зосереджений на клінічних процесах, які забезпечують додану цінність для пацієнта через позитивний вплив на стан його здоров'я. Клінічний процес $€$ суттєвим, головним і найважливішим процесом у системі управління якістю медичної допомоги. Термін «клінічний» розуміється як сукупність всіх типів взаємодій між пацієнтом та медичними працівниками, незалежно від їх спеціалізації.

Початковий стан здоров'я пацієнта, з яким він звертається за медичною допомогою, є об'єктом клінічного процесу на «вході». Зміни в стані здоров'я в результаті клінічної діяльності - це «вихід» процесу, а сама клінічна діяльність - це та сукупність дій, яка перетворює «входи» клінічного процесу на «виходи».

Клінічні процеси в закладі охорони здоров'я повинні бути визначені за видами проблем зі здоров'ям, відповідно, основних замовників групують за однаковим видом проблем зі здоров'ям. Це означає, що увага керівників різних рівнів управління закладу охорони здоров'я при менеджменті клінічних процесів повинна концентруватись на групах пацієнтів з однаковою патологією, а не на структурних підрозділах, де вони отримують медичну допомогу.

Клінічний процес тісно пов'язаний з процесами забезпечення ресурсами та менеджменту.
Неклінічні процеси впливають на якість результатів клінічної діяльності та включають, зокрема, управління знаннями. Знання безпосередньо застосовують в клінічних процесах і тісно пов'язані з компетентністю персоналу, який є носієм цих знань.

Керівник закладу як відповідальна особа повинен скеровувати систему управління якістю на розвиток і підтримку медичних знань, забезпечення застосування медичними працівниками найкращих наявних знань при наданні медичної допомоги шляхом організації навчання, накопичення знань, заохочення обміну та поширення знань в організації.

Підвищення рівня знань, за позиціями стандарту для сорери охорони здоров'я, можливе шляхом включення в систему управління якістю, крім клінічних процесів, двох інших типів процесів - навчальних та/або дослідних медичних процесів, внаслідок того, що вони також орієнтовані безпосередньо на замовника. Навчальний процес уособлює усі види навчань, які пов'язані з набуттям базової професійної освіти або підвищенням кваліфікації. Проведення наукових досліджень на базі закладів охорони здоров'я спрямовані на отримання нових знань в сорері управління якістю медичної допомоги й використання їх у практичній діяльності.

Зазначені типи процесів відсутні в стандарті «ДСТУ ISO 9001:2015 (ISO 9001:2015, IDT). Системи управління якістю. Вимоги» і вперше введені в стандарт для сорери охорони здоров'я (табл. 1).

Основою та фрундаментом системи управління якістю в закладах охорони здоров'я, за вимогами стандарту, є управління клінічними процесами на основі циклу Демінга - PDCA (Плануй - Виконуй - Перевіряй - Впроваджуй зміни) та ризик-орієнтованого мислення.

Ризик-орієнтоване мислення в сфері охорони здоров'я пов'язують з необхідністю забезпечення безпеки пацієнта та розробкою превентивних заходів стосовно ризиків при їх взаємодії з закладом охорони здоров'я. Основними ризиками, що впливають на стан здоров'я пацієнта, визначені клінічні ризики.

Клінічні ризики варто розглядати стосовно одинадцяти наведених вище характеристик якості в сорері охорони здоров'я. На них потрібно зосереджувати увагу та розробляти заходи щодо усунення, зменшення або мінімізації можливостей їх реалізації.

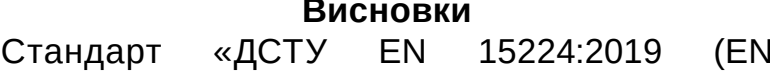
15224:2016, IDT). Системи управління якістю. EN ISO 9001:2015 у сорері охорони здоров'я» після введення в дію слугуватиме надійним інструментом для керівників закладів охорони здоров'я при розробці, впровадженні та підтримці 
Таблиця 1. Структура процесів у системі управління якістю медичної допомоги (за «ДСТУ ЕN 15224:2019 (EN 15224:2016, IDT). Системи управління якістю. EN ISO 9001:2015 у сфері охорони здоров'я»)

\begin{tabular}{|c|c|c|}
\hline № $3 / \Pi$ & Типи процесів & Приклади \\
\hline 1 & $\begin{array}{l}\text { Клінічні } \\
\text { процеси }\end{array}$ & $\begin{array}{l}\text { Профрілактика, діагностика, лікування, реабілітація, екстрена допомога, хоспісна } \\
\text { допомога }\end{array}$ \\
\hline 2 & $\begin{array}{l}\text { Управління } \\
\text { ресурсами }\end{array}$ & $\begin{array}{l}\text { 2.1. Управління людськими ресурсами } \\
\text { 2.2. Управління інфрраструктурою } \\
\text { 2.3. Управління середовищем для функціонування процесів } \\
\text { 2.4. Управління ресурсами для моніторингу та вимірювань } \\
\text { 2.5. Управління знаннями } \\
\text { 2.6. Управління задокументованою інфрормацією } \\
\end{array}$ \\
\hline 3 & Менеджмент & $\begin{array}{l}\text { 3.1. Розробка політики та цілей в сфері якості } \\
\text { 3.2. Планування діяльності з забезпечення якості медичної допомоги } \\
\text { 3.3. Розподіл функцій, повноважень та обов'язків у системі управління якістю } \\
\text { 3.4. Координація діяльності в системі управління якістю } \\
\text { 3.5. Аналіз функціонування системи управління якістю } \\
\text { 3.6. Прийняття рішень з покращення якості процесів і системи } \\
\end{array}$ \\
\hline 4 & $\begin{array}{l}\text { Навчальні } \\
\text { процеси }\end{array}$ & $\begin{array}{l}\text { Навчання медичних працівників у закладі охорони здоров'я за цільовою тематикою, } \\
\text { спрямованою на характеристики якості медичної допомоги }\end{array}$ \\
\hline 5 & $\begin{array}{l}\text { Дослідні } \\
\text { процеси }\end{array}$ & $\begin{array}{l}\text { Проведення наукових досліджень на базі закладів охорони здоров'я, спрямованих на } \\
\text { отримання нових знань в сорері управління якістю медичної допомоги та використання } \\
\text { їх у практичній діяльності }\end{array}$ \\
\hline
\end{tabular}

фрункціонування системи управління якістю медичної допомоги.

Корисність документа полягає в однозначному трактуванні специфрічних понять стосовно якості та наявності додаткових роз'яснень щодо особливостей діяльності в системі управління якістю при наданні медичної допомоги.
Перспективи подальших досліджень в цьому напрямку полягають в оцінці систем управління якістю медичної допомоги, які будуть функціонувати на основі вимог стандарту «ДСТУ ЕN 15224:2019 (EN 15224:2016, IDT). Системи управління якістю. EN ISO 9001:2015 у сфері охорони здоров'я» після введення його в дію в Україні.

\section{Список літератури}

1. Безродна С. М. Управління якістю : навчальний посібник для студентів економічних спеціальностей / С. М. Безродна. - Чернівці : ПВКФ «Технодрук», 2017. - 174 с.

2. Глєбова А. О. Системи управління якістю на підприємстві в умовах євроінтеграційних процесів [Електронний ресурс] / А. О. Глєбова, Б. О. Карчевський // Глобальні та національні проблеми економіки. - 2015. - № 8. С. 352-356. - Режим доступу : http://global-national.in.ua/issue-8-2015/16-vipusk-8-listopad-2015-r/1450-glebova-a-0karchevskij-b-o-sistemi-upravlinnya-yakistyu-na-pidpriemstvi-v-umovakh-evrointegratsijnikh-protsesiv (дата звернення: 05.08.2019). - Назва з екрана.

3. Звіт Головної акредитаційної комісії при МОЗ України за 2018 рік [Електронний ресурс] / МОЗ України. - Режим доступу : http://moz.gov.ua/uploads/2/10966-zvit_gak_2018.pdf (дата звернення: 05.08.2019). - Назва з екрана.

4. Звіт Головної акредитаційної комісії при МОЗ України за 2017 рік [Електронний ресурс] / МОЗ України. - Режим доступу : http://moz.gov.ua/uploads/1/5004-zvit_gak_2017.pdf (дата звернення: 05.08.2019). - Назва $з$ екрана.

5. Конституція України : Закон України від 28 червня 1996 року № 30 із змінами [Електронний ресурс]. - Режим доступу : https://zakon.rada.gov.ua/laws/show/254\%D0\%BA/96-\%D0\%B2\%D1\%80 (дата звернення: 05.08.2019). Назва з екрана.

6. Національна стратегія ресормування системи охорони здоров'я в Україні на період 2015-2020 рр. [Електронний ресурс] / МОЗ України. - Режим доступу : http://moz.gov.ua/uploads/0/691-strategiya.pdf (дата звернення: 05.08.2019). Назва з екрана.

7. Про внесення змін до наказу МОЗ України від 14 березня 2011 р. № 142 «Про вдосконалення державної акредитації закладів охорони здоров'я» : наказ МОЗ України від 20.12.2013 р. № 1116 [Електронний ресурс]. - Режим доступу : https://zakon.rada.gov.ua/laws/show/z0031-14 (дата звернення: 05.08.2019). - Назва з екрана.

8. Про внесення змін до постанов Кабінету Міністрів України від 15 липня 1997 р. № 765 і від 2 березня 2016 р. № 285 : Постанова КМУ від 13 березня 2019 р. № 215 [Електронний ресурс]. - Режим доступу : https://zakon.rada. gov.ua/laws/show/215-2019-\%D0\%BF (дата звернення: 05.08.2019). - Назва з екрана.

9. Сайт ДП «Український науково-дослідний і навчальний центр проблем стандартизації, сертифрікації та якості». Системи управління якістю. EN ISO 9001:2015 у сорері охорони здоров'я [Електронний ресурс]. - Режим доступу : http://shop.uas.org.ua/ua/katalog-normativnih-dokumentiv/11-okhorona-zdorovya/11-020-medychni-nauky-ta-umovyzabezpechennia-okhorony-zdorovia-vzahali/11-020-01-upravlinnja-jakistju-ta-ekologichne-upravlinnja-u-sferi-ohoronizdorov-ja/sistemi-upravlinnja-jakistju-en-.html (дата звернення: 05.08.2019). - Назва з екрана. 
10. Системи управління якістю. Вимоги (ISO 9001:2015, IDT) : ДСТУ ISO 7000:2004 [Електронний ресурс]. - K. : ДП «УкрНДНЦ», 2016 (Національний стандарт України). - Режим доступу : http://khoda.gov.ua/image/catalog/files/\%20 9001.pdf (дата звернення: 05.08.2019). - Назва з екрана.

11. Степурко Т. Г. Задоволеність доступністю та якістю медичної допомоги в Україні, Польщі та Угорщині / Т. Г. Степурко // Наукові записки НаУКМА. - 2016. - Т. 187. Соціологічні науки. - С. 82-89.

12. Akachia Yoko. Quality of care: measuring a neglected driver of improved health / Yoko Akachia, Margaret E Krukb // Bull World Health Organ. - 2017. - No 95. - P. 465-472. doi: http://dx.doi.org/10.2471/BLT.16.180190.

13. Handbook for national quality policy and strategy: a practical approach for developing policy and strategy to improve quality of care. - Geneva: WHO, 2018. - 88 p.

14. ISO 9001:2015. Quality management systems - Requirements (International standard) [Electronic resource]. - Regime of access: https://www.iso.org/ru/standard/62085.html.

\section{References}

1. Bezrodna, S.M. (2017). Upravlinnia yakistiu [Quality management]. Chernivtsi: PVKF "Tekhnodruk" [in Ukrainian]. 2. Hliebova, A.O., \& Karchevskyi, B.O. (2015). Systemy upravlinnia yakistiu na pidpryiemstvi v umovakh yevrointehratsiinykh protsesiv [Quality management systems at the enterprise in the context of European integration processes]. Hlobalni ta natsionalni problemy ekonomiky - Global and National Problems of Economy, 10. Retrieved from: http://global-national. in.ua/issue-8-2015/16-vipusk-8-listopad-2015-r/1450-glebova-a-o-karchevskij-b-o-sistemi-upravlinnya-yakistyu-napidpriemstvi-v-umovakh-evrointegratsijnikh-protsesiv [in Ukrainian].

3. MOZ Ukrainy (2019). Zvit holovnoi akreditatsiinoi komisii pry MOZ Ukraini za 2018 rik [Report of the Main Accreditation Commission of the Ministry of Health of Ukraine for 2018]. Retrieved from: http://moz.gov.ua/uploads/2/10966-zvit_ gak_2018.pdf [in Ukrainian].

4. MOZ Ukrainy (2018). Zvit holovnoi akredytatsiinoi komisii pry MOZ Ukrainy za 2017 rik [Report of the Main Accreditation Commission of the Ministry of Health of Ukraine for 2017]. Retrieved from: http://moz.gov.ua/uploads/1/5004-zvit_gak_2017. pdf [in Ukrainian].

5. Zakon Ukrainy "Konstytutsiia Ukrainy" [The Law of Ukraine "Constitution of Ukraine"]. Retrieved from: https://zakon. rada.gov.ua/laws/show/254\%d0\%ba/96-\%d0\%b2\%d1\%80 [in Ukrainian].

6. Natsionalna stratehiia reformuvannia systemy okhorony zdorovia v Ukraini na period 2015-2020 rokiv [National Strategy for Healthcare Reform in Ukraine for the period 2015 - 2020]. Retrieved from: http://moz.gov.ua/uploads/0/691-strategiya. pdf [in Ukrainian].

7. MOZ Ukrainy (2013). Pro vnesennia zmin do nakazu MOZ Ukrainy vid 14 bereznia 2011 roku № 142 «Pro vdoskonalennia derzhavnoi akredytatsii zakladiv okhorony zdorovia»: nakaz MOZ Ukraini vid 20.12.2013 r. № 1116. [On Amendments to the Order of the Ministry of Health of Ukraine of March 14, 2011 No. 142 "On Improvement of State Accreditation of Health Care Institutions": Order of the Ministry of Health of Ukraine of December 12, 2013 No. 1116]. Retrieved from: https://zakon. rada.gov.ua/laws/show/z0031-14 [in Ukrainian].

8. KMU Ukrainy (2019). Pro vnesennia zmin do postanov Kabinetu Ministriv Ukrainy vid 15 lipnia 1997 r. № 765 i vid 2 bereznia 2016 r. № 285 [On Amendments to the Resolutions of the Cabinet of Ministers of Ukraine of July 15, 1997 No. 765 and of March 2, 2016 No. 285]. Retrieved from: https://zakon.rada.gov.ua/laws/show/215-2019-\%d0\%bf [in Ukrainian].

9. Sait DP Ukrainskyi naukovo-doslidnyi i navchalnyi tsentr problem standartyzatsii, sertyfikatsii ta yakosti. Systemy upravlinnia yakistiu. EN ISO 9001:2015 u sferi okhorony zdorovia [Site Ukrainian Research and Training Center for Standardization, Certification and Quality. Quality management systems. EN ISO 9001: 2015 for healthcare]. Retrieved from: http://shop.uas.org.ua/ua/katalog-normativnih-dokumentiv/11-okhorona-zdorovya/11-020-medychni-nauky-taumovy-zabezpechennia-okhorony-zdorovia-vzahali/11-020-01-upravlinnja-jakistju-ta-ekologichne-upravlinnja-u-sferiohoroni-zdorov-ja/sistemi-upravlinnja-jakistju-en-.html [in Ukrainian].

10. DSTU ISO 9001:2015 (ISO 9001:2015, idt). Systemy upravlinnia yakistiu. Vymohy (2016) [DSTU ISO $9001: 2015$ (ISO 9001: 2015, IDT). Quality management systems. Requirements] Kyiv: DP «UkrNDNC». Retrieved from: http://khoda.gov. ua/image/catalog/files/\%209001.pdf [in Ukrainian].

11. Stepurko, T.H. (2016). Zadovolenist dostupnistiu ta yakistiu medychnoi dopomohy v Ukraini, Polshchi ta Uhorshchyni [Satisfaction with the availability and quality of care in Ukraine, Poland and Hungary]. Naukovi zapysky NaUKMA, Sotsiolohichni nauky - NaUKMA Scientific Note, Sociological Sciences, 187, 82-89 [in Ukrainian].

12. Akachia Yoko, \& Margaret E. Krukb (2017). Quality of care: measuring a neglected driver of improved health. Bull World Health Organ., 95, 465-472. doi: http://dx.doi.org/10.2471/blt.16.180190.

13. WHO (2018). Handbook for national quality policy and strategy: a practical approach for developing policy and strategy to improve quality of care. Geneva: WHO.

14. ISO 9001:2015. Quality management systems - Requirements. Retrieved from: https://www.iso.org/ru/standard/62085.html.

\section{ПЕРСПЕКТИВЫ ИСПОЛЬЗОВАНИЯ СТАНДАРТОВ НА СИСТЕМЫ УПРАВЛЕНИЯ КАЧЕСТВОМ В УЧРЕЖДЕНИЯХ ЗДРАВООХРАНЕНИЯ}

А. Г. Круть, В. В. Горачук

Национальная медицинская академия последипломного образования имени П. Л. Шупика, г. Киев, Украина

Цель: определить отличия требований стандарта «ДСТУ EN 15224:2019 (EN 15224:2016, IDT). Системы управления качеством. EN ISO 9001:2015 в сорере здравоохранения» от стандарта «ISO 9001:2015 (ISO 9001:2015, IDT). Системы управления качеством. Требования». 
Материалы и методы. Использованы научные литературные источники, отечественные и международные документы, стандарты на системы менеджмента качества. Применяли методы системного подхода, системного и сравнительного анализа, контент-анализа, графический.

Результаты. В специфическом для сфреры здравоохранения стандарте более подробно представлены характеристики качества медицинской помощи (соответствие потребностям пациента, доступность, непрерывность, эффрективность, результативность, беспристрастность, безопасность, своевременность, научная обоснованность, ориентированность на пациента, вовлеченность пациента) в отличие от существующих (эффрективность, результативность, справедливость, ориентированность на пациента, безопасность, своевременность). Уточнено понятие потребностей пациента в медицинской помощи как отклонение текущего состояния здоровья от желаемого. Отмечено, что процессный подход в учреждении здравоохранения должен быть осредоточен на клинических процессах, а риск-ориентированное мышление - на безопасности пациента и разработке превентивных мер. Рекомендуется осуществлять управление клиническими процессами на основе цикла Деминга (PDCA). Структура процессов представлена клиническими процессами, процессами управления ресурсами, менеджмента, исследовательскими и учебными процессами. Подчеркнута важность фрормирования, накопления и использования собственной базы знаний в учреждениях здравоохранения.

Выводы. Исследуемый стандарт, специфический для сферы здравоохранения, после введения в действие в Украине, дополнит арсенал управленческих инструментов по разработке, внедрению и поддержке фрункционирования систем управления качеством в учреждениях здравоохранения.

КЛЮЧЕВЫЕ СЛОВА: стандарт; система управления качеством; учреждения здравоохранения; медицинская помощь.

\section{PROSPECTS FOR THE USE OF STANDARDS FOR QUALITY MANAGEMENT SYSTEMS IN HEALTHCARE INSTITUTIONS}

A. G. Krut, V. V. Gorochuk

P. Shupyk National Medical Academy of Postgraduate Education, Kyiv, Ukraine

Purpose: to determine the differences in the requirements of the standard "DSTU EN 15224: 2019 (EN 15224: 2016, IDT). Quality management systems. EN ISO 9001: 2015 for healthcare" from the requirements of the universal standard "DSTU ISO 9001: 2015 (ISO 9001: 2015, IDT). Quality management systems. Requirements".

Materials and Methods. Scientific literary sources, domestic and international documents, standards for quality management systems were used. Methods of a systematic approach, systemic and comparative analysis, content analysis, graphic were applied.

Results. The characteristics of the quality of medical care are presented in more detail (appropriate, correct care, accessibility, continuity of care, effectiveness, efficiency, equity, patient safety, timeliness, evidence/ knowledge based care, patient centred care, patient involvement) in a standard specific to the healthcare sector, unlike the existing ones (efficiency, effectiveness, patient focus, patient safety, timeliness). The concept of patient needs for medical care is specified as the deviation of the current state of health from the desired. It is noted that the process approach in a healthcare institution should be focused on clinical processes, and risk-based thinking should be directed to patient safety and the development of preventive measures. It is recommended that clinical processes should be managed based on the Deming Cycle (PDCA). The structure of the processes is represented by clinical processes, resource management processes, management, research and educational processes. The importance of the formation, accumulation and use of their own knowledge base in a health care institution was emphasized.

Conclusions. The studied standard, specific to the healthcare sector, will complement the arsenal of management tools for the development, implementation and support of the functioning of quality management systems for medical care in healthcare institutions after they have been put into effect in Ukraine.

KEY WORDS: standard; quality management system; healthcare institutions; healthcare.

Рукопис надійшов до редакції 03.09.2019 p.

\section{Відомості про авторів:}

Круть Анатолій Григорович - кандидат медичних наук, доцент, директор Стоматологічного практичнонавчального медичного центру Національної медичної академії післядипломної освіти імені П. Л. Шупика; тел.: +38(044) 234-20-29.

Горачук Вікторія Валентинівна - доктор медичних наук, професор, професор кафедри управління охороною здоров'я Національної медичної академії післядипломної освіти імені П. Л. Шупика; тел.: +38(044) 205-49-93. 